\title{
Environmental structure and relationships in the setting of natural water springs in a Lower Highland Seasonal Forest in Brazilian South
}

\author{
Paulo Alfonso Floss $^{1^{*}}$ Solon Jonas Longhi ${ }^{2}$ \\ Malcon do Prado Costa $^{3}$ - Elzira Cecília Serafini Floss ${ }^{4}$
}

\begin{abstract}
${ }^{1}$ Empresa de Pesquisa Agropecuária e Extensão Rural de Santa Catarina, Servidão Ferdinando Tusset, S/N, 89803-904, Chapecó, SC, Brasil. E-mail: pfloss@epagri.sc.gov.br. "Corresponding author.

${ }^{2}$ Departamento de Ciências Florestais, Universidade Federal de Santa Maria (UFSM), Santa Maria, RS, Brasil.

${ }^{3}$ Programa de Pós-Graduação em Ciências Florestais, Escola Agrícola de Jundiaí, Unidade Acadêmica Especializada em Ciências Agrárias, Universidade Federal do Rio Grande do Norte (UFRN), Macaíba, RN, Brasil.

${ }^{4}$ Secretaria da Educação do Estado de Santa Catarina, Chapecó, SC, Brasil.
\end{abstract}

\begin{abstract}
The aim of this research was to characterize an environmental structure in the setting of tree natural water springs in a Lower Highland Seasonal Forest, and to verify the relationship between community demography and soil variables as subsidies for species identification in riparian forest recovery programs in similar environments. The research was carried out in the National Forest of Chapecó, located in the west of the state of Santa Catarina in the southern region of Brazil. For this, three water springs were demarcated, where 26 plots of $200 \mathrm{~m}^{2}$ in each were allocated. All individuals with diameter at $1.30 \mathrm{~m}$ of soil height $\geq 5.0 \mathrm{~cm}$ were measured. Soil samples (0 to $20 \mathrm{~cm}$ depth) were collected in the plots for chemical and physical analysis. To relate the abundance of the species to the edaphic variables, the Canonical Correspondence Analysis (CCA) was used. A total of 76 species belonging to 64 genera of 36 botanical families were reported in the study area. The families Fabaceae and Myrtaceae presented greater floristic richness. The edaphic variables that most influenced the distribution of the species were aluminum saturation and calcium, magnesium and potassium contents. Specific groups of indicator species were formed for each water spring. The species designated as generalists are the most recommended for the initial filling and recovery of degraded springs. Further rare species and with low density must be included after the initial recovery to increase diversity.
\end{abstract}

Key words: Riparian Forest, Atlantic Forest, Fragmentation, Edaphic Variables, Forest Recovery.

Estrutura e relações ambientais no entorno de nascentes em uma Floresta Latifoliada Subtropical no Sul do Brasil

RESUMO: O presente trabalho teve como objetivo caracterizar a vegetação arbórea em nascentes de Floresta Latifoliada Subtropical e verificar a relação entre a demografia da comunidade e variáveis edáficas, como subsídios para indicação de espécies em programas de recuperação de florestas ciliares de ambientes similares. O trabalho foi realizado na Floresta Nacional de Chapecó, localizada no oeste do estado de Santa Catarina no sul do Brasil. Para isso, foram demarcadas três nascentes, onde foram alocadas 26 parcelas de $200 m^{2}$ em cada uma. Todas as árvores com Diâmetro a Altura do Peito (DAP) $\geq 5,0 \mathrm{~cm}$ a 1,30m de altura do solo foram mensurados. Coletaram-se amostras de solo (0 a $20 \mathrm{~cm}$ de profundidade) nas parcelas para análise das propriedades químicas e fisicas. Para relacionar a abundância das espécies com as variáveis edáficas utilizou-se a Análise de Correspondência Canônica (CCA). Foram encontradas na área de estudo, 76 espécies pertencentes a 64 gêneros de 36 famílias botânicas. As famílias Fabaceae e Myrtaceae apresentaram maior riqueza florística. As variáveis edáficas que mais influenciaram na distribuição das espécies foram a saturação por aluminio e os teores de cálcio, magnésio e potássio. Ocorreu a formação de grupos especificos de espécies indicadoras para cada nascente. As espécies designadas como generalistas são as mais recomendadas para a recomposição de nascentes com a função de preenchimento inicial da área. Enquanto as espécies raras e de baixa densidade devem ser incluídas após a recuperação inicial com a função de aumentar a diversidade.

Palavras-chave: Floresta ciliar, Mata Atlântica, Fragmentação, Variáveis ambientais, Recomposição florestal.

\section{INTRODUCTION}

Forests have an important role in the quality of the available water and maintain the integrity of water springs, streams, rivers and other reservoirs. Knowing the forests is essential for their conservation and for the provision of subsidies for recovery programs of springs and riparian forests, thus maintaining and enhancing the quality of water. Due to its priceless value, the water spring within a rural property must have special attention (CALHEIROS et al., 2004). 
West of the State of Santa Catarina in Brazil, studies related to the influence of environmental variables in the distribution and amount of forest species are recent and not very developed, especially in the remaining of the Lower Highland Seasonal Forest, which is an important part of the Atlantic Forest biome. Thus, researches developed around water springs and riparian forests in this region have a high scientific relevance.

Great part of the West of the State of Santa Catarina is located in altitudes ranging from 500 to $900 \mathrm{~m}$. The central portion of this region presents a great variation in both soil and climate, having a high economic importance within the State and a predominance of the agro industrial activities, which depends on the availability and quality of water. The Lower Highland Seasonal Forest is inserted in this area (OLIVEIRAFILHO, 2009), and many authors such as LEITE \& KLEN (1990) denominate it as a Transition Forest because it is located between the Submontana Seasonal Forest and the Mixed Ombrophilous Forest (IBGE, 2012), having many species of both phytogeographic formations as well as its own characteristics. OLIVEIRA-FILHO (2009) denominates it as Lower Highland Seasonal Forest based on the classification made by VELOSO et al. (1991), which considers the altitude gradient.

This phytogeographic formation presents some important characteristics that differ from those of Uruguay River Seasonal Forest (altitude ranging from 200 to $500 \mathrm{~m}$ ). AA highlight is the significant presence of Ilex paraguariensis in the research area, which is usually absent in most part of Uruguay River Seasonal Forest. Other preferred species in the Lower Highland Seasonal Forest are Diatenopteryx sorbifolia, Ateleia glazioveana and Alsophila setosa, according to studies by REITZ et al. (1983) and VACCARO \& LONGHI (1995) in the state of Rio Grande do Sul, near the study area.

In this context, the aim of the present research was to answer the questions: Were the study springs well conserved? Did they present typical floristic composition of Lower Highland Seasonal Forest? Which species can be indicated for restoration of degraded springs in similar environments? To answer these, the following goals were stablished: a) to know the floristic composition and phytosociological structure in springs surroundings of Lower Highland Seasonal Forest; b) to verify the relation between the distribution of the species and edaphic variables; c) to verify the existence of species indicator groups for each spring; d) to indicate species for recovery of degraded springs.

\section{MATERIALS AND METHODS}

The three water springs of the Lower Highland Seasonal Forest were located in forest fragments of the National Forest of Chapecó (FLONA): the springs 1 (WS1) and 2 (WS2) in the municipality of Guatambu, SC, and the spring 3 (WS3) in the municipality of Chapecó, SC. The geographical coordinates (latitude and longitude) and altitude of the three springs are: WS 1 ( $27^{\circ} 06^{\prime} 28^{\prime}$ 'S, $52^{\circ} 47^{\prime} 05^{\prime \prime} \mathrm{W}$ and $\left.513 \mathrm{~m}\right)$; WS2 (27 $06^{\circ} 21^{\prime \prime} \mathrm{S}, 52^{\circ}$ $46^{\prime} 50^{\prime \prime} \mathrm{W}$ and $\left.585 \mathrm{~m}\right)$; WS3 (27 $10^{\circ} 55^{\prime} \mathrm{S}, 52^{\circ} 36^{\prime}$ 51 'W and $685 \mathrm{~m}$ ) (Figure 1). The sampling method used was a cross-transect (adapted from PINTO et al., 2005), in which 26 rectangular parcels (sample units of $20 \times 10 \mathrm{~m}$ ) were allocated, totaling $5,200 \mathrm{~m}^{2}$ sampled at each spring.

All trees with diameter at breast height $(\mathrm{DBH}) \geq 5.0 \mathrm{~cm}$ at $1.30 \mathrm{~m}$ of soil were measured and identified. The total height of each individual was also estimated, including arborescent ferns. Botanical material of the species was collected for later identification in the Herbarium of the Department of Forest Sciences (HDCF) of the Universidade Federal de Santa Maria (UFSM). Species of difficult identification were sent to specialists. To determine the physical and chemical properties of the soil, eight simple samples of the superficial soil $(0-20 \mathrm{~cm}$ deep) were collected with a soil auger. These samples were mixed and homogenized to form composite samples $\left(200 \mathrm{~m}^{2}\right)$. For the physical analysis $200 \mathrm{~g}$ of soil sample were taken into account, whose proportion of sand, silt and clay were measured according to CLAESSEN (1997) and PRADO (2005). Other 200g of soil was put into aluminum capsules in order to determine their gravimetric water soil content $(\mathrm{Ug} \%)$, also according to CLAESSEN (1997). For the chemical analysis performed with the remaining amount of soil, the methodology of TEDESCO et al. (1995) was taken into account, with the following variables being analyzed: $\mathrm{pH}$ (Water), P, K, Al, Ca, Mg, potential acidity $(\mathrm{H}+$ $\mathrm{Al})$, organic matter $(\mathrm{OM})$, cation exchange capacity (CEC), sum of $(\mathrm{S})$, base saturation (V\%), saturation with aluminum (m\%), $\mathrm{Ca} / \mathrm{Mg}, \mathrm{Ca} / \mathrm{K}$ and $\mathrm{Mg} / \mathrm{K}$.

The description of the forest around the springs was performed based on the parameters of the horizontal structure of the species. The floristic composition was evaluated from the list of species, genera and botanical families of the tree community, using the Angiosperm Phylogeny Group Classification System (APG IV, 2016). The parameters of the horizontal structure studied were absolute density $(\mathrm{DA}=\mathrm{ni} / \mathrm{ha})$, absolute dominance $(\mathrm{DoA}=\Sigma \mathrm{g} / \mathrm{ha})$, 


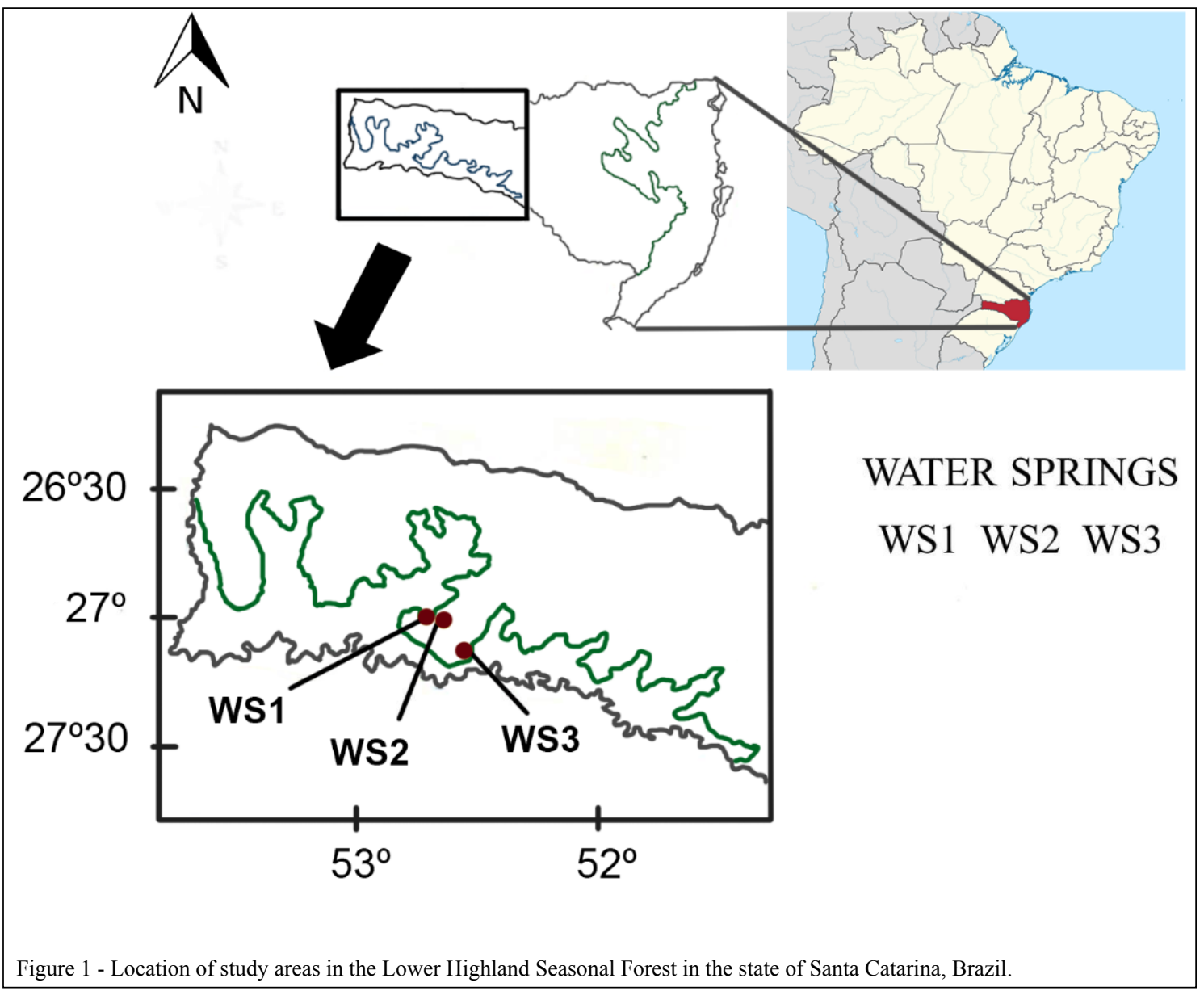

absolute frequency $(\mathrm{FA}=$ percentage of plots where each species occurs) and importance value (VI\%) of species, where ni is the number of individuals and $\mathrm{g}$ is the basal area of each specie (MUELLERDOMBOIS \& ELLENBERG, 2002).

For the statistical analyzes, the differences in the soil variables between the springs were verified by analysis of variance (ANOVA) followed by a Tukey (q) test, with a significance level of $95 \%$, processed by the statistical program R 2.10 (R DEVELOPMENT CORE TEAM, 2006).

In order to verify the correlation between the species distribution and the edaphic variables, the Canonical Correspondence Analysis (CCA), developed by TER BRAAK $(1986 ; 1995)$, was used. The species abundance matrix consisted of the number of individuals per plot of the species that presented 10 or more individuals in the set of 78 plots (26 plots per water spring), since rare species interfere very little in the results of the ordering (GAUCH, 1982) and, if present, hamper the interpretation of the CCA.
With this, the abundance matrix remained with 35 species. The second matrix was composed of the 18 soil variables previously mentioned in the set of 78 plots. To verify significance of the species-variable environmental relationships in the explanation of the variation in the value of the ordering axes, the Monte Carlo Permutation test was performed.

An Analysis of Indicating Species (ISA) was applied in the species abundance matrix. This method combines the abundance of each species with a certain group of sample units, as well as the fidelity of the occurrence of this species to this same group (DUFRÊNE \& LEGENDRE, 1997). The CCA and ISA analyzes were processed by PC-ORD for Windows version 5.0 (McCUNE \& MEFFORD, 2006).

The species recommendation was performed based on the functional strategies of the plants for environmental recovery (RODRIGUES et al., 2011). Generalist species, due to their higher plasticity and the quality to develop in majority of places, are recommended as a functional strategy of 
filling. These species have rapid growth and are ideal for initial coverage around the springs. Species that responded to the environmental gradients, showing high abundance and were indicative of ISA, are recommended according to the edaphic characteristics of the recovering area. Finally, low density and rare species have the functional strategy of maintaining diversity and are recommended after the spring initial recovery.

\section{RESULTS AND DISCUSSION}

\section{Floristic Composition}

A total of 76 species belonging to 64 genera and 36 botanical families were identified. The Fabaceae family presented 10 species, followed by Myrtaceae (8), Lauraceae (6), Sapindaceae (5), Meliaceae and Rutaceae (4). The families Rubiaceae, Sapindaceae and Lauraceae presented greater abundance of individuals. Of the 36 families, 23 presented only one species. These families are characteristic and dominant in the seasonal forests of southern Brazil, as shown by VACCARO \& LONGHI (1995), LONGHI et al. (2000), SCHNEIDER \& ROCHA (2014) and the Mixed Ombrophilous Forests, according to KLAUBERG et al. (2010); NASCIMENTO et al. (2011) and GASPER et al. (2013), among others.

It is seen that the arboreous vegetation in the analyzed water springs are well conserved, showing a high variety of species. The species Coussarea contracta, Luehea divaricata, Ocotea odorifera, Diatenopteryx sorbifolia, Alsophyla setosa, Nectandra megapotamica, Cupania vernalis, Ateleia glazioveana, Casearia sylvestris and Trichilia elegans were the 10 species $(13.16 \%)$ that most characterized the Forest, presenting together $52.27 \%$ of the total importance value (IV) of the species within the vegetation close to the water springs. The remaining 66 species $(86.84 \%)$ of the species correspond to the other $47.73 \%$ of the IV.

The most abundant species in the springs were Coussarea contracta, Diatenopteryx sorbifolia, Alsophyla setosa, Ocotea indecora, Nectandra megapotamica, Cupania vernalis, Casearia sylvestris, Trichilia elegans, Cordia americana, Allophylus edulis, Luehea divaricata, Campomanesia xanthocarpa, Ateleia glazioveana, Myrocarpus frondosus and Ilex paraguariensis. These 16 species ( $21 \%$ of the total) contributed with 105 ind.ha $^{-1}(77$ $\%$ of the total). The remaining 60 species $(79 \%)$ contributed with only $23 \%$ of the total of individuals reported in this research.
The most dominant species that showed higher value of basal area were Luehea divaricata, Ocotea indecora, Ateleia glazioveana, Cupania vernalis, Araucaria angustifolia, Nectandra lanceolata, Cryptocarya moschata, Coussarea contracta, Nectandra megapotamica and Diatenopteryx sorbifolia, presenting a basal area of $24.91 \mathrm{~m}^{2} \cdot \mathrm{ha}^{-1}(62.28 \%$ of the total).

It is important to also highlight the dead trees, which have the $7^{\text {th }}$ greater density of individuals $\left(52\right.$ ind.ha $\left.^{-1}\right)$ and the $3^{\text {rd }}$ greater basal area $\left(2.05 \mathrm{~m}^{2} \cdot \mathrm{ha}^{-1}\right)$. Due to the small values for number of individuals and basal area, it is possible to deduce that old individuals with great diameter died suppressed by the forest canopy. The presence in the native forests of individuals that are in the top ten in a scale of densities is common in any forest tipology, according to VACCARO \& LONGHI (1995); LONGHI et al. (2000); NASCIMENTO et al. (2011); CALLEGARO et al. (2012).

Only three species presented an absolute frequency higher than 50\%: Coussarea contracta $(91,03 \%)$, Ocotea indecora $(67,95)$ e Diatenopteryx sorbifolia $(60,26 \%)$, which are the most spread in the surroundings of the water springs.

From the species present in the water springs it is possible to observe that the Lower highland Seasonal Forest is typical in forest formations in the High Uruguai of both states of Santa Catarina and Rio Grande do Sul, they are very different from the Seasonal Deciduous Forest of the Central Depression of the State of Rio Grande do Sul. This observation comes from the occurrence of some exclusive species, such as Ateleia glazioveana, Balfourodendron riedelianum, Coussarea contracta, Diatenopteryx sorbifolia, Holocalyx balansae, Peltophorum dubium and Pilocarpus pennatifolius. Besides it, they show some typical species of the Mixed Ombrophilous Forest, such as Alsophila setosa, Chryptocarya aschersoniana, Dicksonia sellowiana, Lamanonia ternata, Ocotea indecora, Piptocarpha angustifolia, amongst others, proving that the streams are in regions where there is a transition with such forest. These species were also identified by GOMES et al. (2008) and KANIESKI et al. (2010).

\section{Correlation of edaphic species}

Table 1 contains values for averages, standard deviation and variance of the physical and chemical analysis of the soil with a depth of $0-20 \mathrm{~cm}$ for the portions of each stream. Five variables did not present any significant difference in their average values amongst the streams: soil moisture, clay 
Table 1 - Edaphic variables of surface soil (0-20cm) of three water springs of Lower Highland Seasonal Forest, Guatambu and Chapecó, Santa Catarina State, Brazil.

\begin{tabular}{|c|c|c|c|c|c|}
\hline \multirow[t]{2}{*}{ Variables } & \multicolumn{3}{|c|}{ - } & \multicolumn{2}{|c|}{ 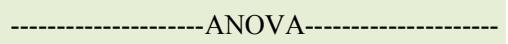 } \\
\hline & WS1 (26) & WS2 (26) & WS3 (26) & $\mathrm{F}$ & $\mathrm{P}$ \\
\hline Soil moisture (\%) & $5.7 \pm 16.60^{\mathrm{a}}$ & $65.2 \pm 25.17^{\mathrm{a}}$ & $60.6 \pm 10.96^{\mathrm{a}}$ & 1.3774 & ns \\
\hline $\mathrm{pH}$ (water) & $4.9 \pm 0.34^{\mathrm{a}}$ & $4.6 \pm 0.21^{b}$ & $4.5 \pm 0.24^{\mathrm{b}}$ & 19.015 & ${ }^{* * *}$ \\
\hline $\mathrm{P}\left(\mathrm{mg} / \mathrm{dm}^{3}\right)$ & $5.0 \pm 1.75^{\mathrm{a}}$ & $4.6 \pm 1.55^{\mathrm{a}}$ & $4.5 \pm 1.18^{\mathrm{a}}$ & 0.8659 & ns \\
\hline $\mathrm{K}\left(\mathrm{mg} / \mathrm{dm}^{3}\right)$ & $82.5 \pm 22.57^{\mathrm{ab}}$ & $71.5 \pm 17.96^{\mathrm{a}}$ & $90.8 \pm 18.81^{\mathrm{b}}$ & 6.2202 & ** \\
\hline $\mathrm{MO} \%(\mathrm{~m} / \mathrm{v})$ & $6.7 \pm 1.45^{\mathrm{a}}$ & $5.6 \pm 1.04^{b}$ & $4.9 \pm 0.41^{b}$ & 18.024 & *** \\
\hline $\mathrm{Al}\left(\mathrm{cmolc} / \mathrm{dm}^{3}\right)$ & $1.9 \pm 1.25^{\mathrm{a}}$ & $3.9 \pm 0.96^{b}$ & $5.0 \pm 1.23^{\mathrm{c}}$ & 50.065 & *** \\
\hline $\mathrm{Ca}\left(\mathrm{cmolc} / \mathrm{dm}^{3}\right)$ & $6.5 \pm 2.88^{\mathrm{a}}$ & $2.1 \pm 1.22^{b}$ & $1.9 \pm 4.05^{b}$ & 19.774 & ${ }^{* * *}$ \\
\hline $\mathrm{Mg}\left(\mathrm{cmolc} / \mathrm{dm}^{3}\right)$ & $2.0 \pm 0.77^{\mathrm{a}}$ & $1.0 \pm 0.49^{b}$ & $0.4 \pm 0.20^{\mathrm{c}}$ & 55.72 & ${ }^{* * *}$ \\
\hline $\mathrm{H}+\mathrm{Al}\left(\mathrm{cmolc} / \mathrm{dm}^{3}\right)$ & $15.8 \pm 6.05^{\mathrm{a}}$ & $21.8 \pm 5.00^{b}$ & $25.3 \pm 6.26^{b}$ & 18.065 & *** \\
\hline CEC $\left(\mathrm{cmolc} / \mathrm{dm}^{3}\right)$ & $24.4 \pm 4.88^{a}$ & $25.1 \pm 4.49^{\mathrm{a}}$ & $27.8 \pm 7.55^{\mathrm{a}}$ & 2.5439 & ns \\
\hline Base saturation $(\%)$ & $36.7 \pm 15.72^{a}$ & $13.7 \pm 7.82^{b}$ & $8.6 \pm 10.49^{b}$ & 41.71 & *** \\
\hline Al Saturation $(\%)$ & $20.7 \pm 16.85^{a}$ & $56.3 \pm 17.70^{b}$ & $72.9 \pm 18.98^{c}$ & 57.781 & *** \\
\hline $\mathrm{Ca} / \mathrm{Mg}$ & $3.2 \pm 0.55^{\mathrm{a}}$ & $2.1 \pm 0.54^{\mathrm{a}}$ & $4.7 \pm 13.05^{\mathrm{a}}$ & 0.7799 & ns \\
\hline $\mathrm{Ca} / \mathrm{K}$ & $32.6 \pm 17.48^{a}$ & $11.5 \pm 5.99^{b}$ & $8.8 \pm 21.68^{b}$ & 16.396 & *** \\
\hline $\mathrm{Mg} / \mathrm{K}$ & $10.0 \pm 4.60^{\mathrm{a}}$ & $5.2 \pm 2.30^{b}$ & $1.8 \pm 0.76^{c}$ & 49.066 & *** \\
\hline Grit (\%) & $28.3 \pm 6.79^{a}$ & $32.0 \pm 9.50^{\mathrm{ab}}$ & $29.2 \pm 2.90^{b}$ & 5.2628 & ** \\
\hline Silt (\%) & $40.0 \pm 4.89^{\mathrm{a}}$ & $50.0 \pm 14.01^{\mathrm{a}}$ & $44.6 \pm 3.12^{b}$ & 5.4414 & ** \\
\hline Clay (\%) & $31.8 \pm 6.19^{a}$ & $18.0 \pm 5.71^{\mathrm{a}}$ & $26.2 \pm 3.90^{\mathrm{a}}$ & 1.6345 & ns \\
\hline
\end{tabular}

Where: ${ }^{*}=$ significance of $5 \% ;{ }^{* *}=$ significance of $1 \% ;^{* * *}=$ significance of $0.1 \%$ when P $(>\mathrm{F})$. Where the variance analysis $($ ANOVA) indicates that there are no significant differences among the water springs, when the average value of the variables are followed by the same letter by the Tukey test $(q)(P \leq 0.05)$. The values are averages \pm standard deviations in the 26 plots in each one of the three springs.

content, phosphorus content, $\mathrm{CEC}$ and $\mathrm{Ca} ; \mathrm{Mg}$ and; therefore, were discarded in the analysis.

The eigenvalues for the first two axes of ordering the canonical correspondence analysis was low ( 0.247 for axis 1 and 0.067 for axis 2$)$, indicating the existence of short gradients, that is, most species occur in most parcels, where only the distribution of their abundances varies. The first two axes explain only $8.4 \%$ (axis 1 ) and $2.3 \%$ (axis 2) of the overall data variance (cumulative total: $10.7 \%$ ), which indicates a lot of "noise" or unexplained remaining variance (TER BRAAK, 1987). Similar values were reported by ESPIRITO-SANTO et al. (2002) in remaining of the Seasonal Montana Semideciduous Forest in Lavras - MG, whose eigenvalues for the first two ordering axis were 0.131 and 0.118 , and explain only $6.7 \%$ and $6.1 \%$ (total $12.9 \%$ ) of the global variance respectively. However, small percentages of variance in the number of species are common in vegetation data and do not interfere in the significance of the species-environment relations (TER BRAAK, 1988; ESPÍRITO-SANTO et al., 2002).

Even so, the significance of the edaphic species-variable relationships was not affected, since the CCA presented high correlations in the first two axes: 0.822 (axis 1) and 0.536 (axis 2). In addition, the Monte Carlo permutation test indicated that species abundances and soil variables were significantly correlated $(\mathrm{P}=0.01)$. Further, the edaphic variables are strongly correlated with the first axis. In decreasing order, the correlations were: magnesium, saturation by aluminum and calcium and, with the second axis, the potassium content (Table 2).

On the axis right side of figure 2A where located in the majority of Water Spring 1 (WS1) plots suggesting a fertility gradient, predominating the Humaqueptic Endoaquents soil (SSS, 2014). On the left side there is a predominance of Water Spring 3 (WS3) plots and Typic Dystrudepts soil (SSS, 2014) with a greater aluminum saturation suggesting acid soils. The Water Spring 2 (WS2) plots are concentrated in the middle gradient with Humaqueptic Endoaquents and Typic Dystrudepts soil (SSS, 2014) and with intermediate predominance in relation to edaphic variables.

From figure $2 \mathrm{~B}$ and table 3 it is possible to relate the following indicator species 
Table 2 - Canonical Correspondence Analysis (CCA) of 78 plots, 35 species and four edaphic variables in three water springs of Lower Highland Seasonal Forest, Guatambu and Chapecó, Santa Catarina State, Brazil.

\begin{tabular}{|c|c|c|c|c|c|c|c|}
\hline \multirow[t]{2}{*}{ Edaphic Variables } & \multicolumn{2}{|c|}{-----Correlation “intraset"------ } & \multicolumn{2}{|c|}{------Correlation “interset"------ } & \multicolumn{3}{|c|}{ Edaphic Variables---- } \\
\hline & Axis 1 & Axis 2 & Axis 1 & Axis 2 & $\mathrm{~K}$ & $\mathrm{Ca}$ & $\mathrm{Mg}$ \\
\hline $\mathrm{K}$ & -0.167 & -0.877 & -0.137 & -0.470 & - & & \\
\hline $\mathrm{Ca}$ & 0.706 & -0.056 & 0.580 & -0.030 & 0.027 & - & \\
\hline $\mathrm{Mg}$ & 0.947 & -0.190 & 0.779 & -0.102 & 0.083 & 0.730 & - \\
\hline Al Sat. & -0.910 & 0.293 & -0.748 & 0.157 & -0.045 & -0.830 & -0.911 \\
\hline
\end{tabular}

Where: $\mathrm{K}=$ potassium, $\mathrm{Ca}=$ calcium, $\mathrm{Mg}=$ magnesium, $\mathrm{Al}$ Sat. = Aluminium saturation $(\mathrm{m})$. Internal "intraset" correlations and among the "intraset" data for the first two ordination axis and the matrix of averaged correlations amongst the variables. Correlations $>0.5$ are in bold.

for the water spring (WS1): Sorocea bonplandii, Trichilia elegans, Cabralea canjerana, Diatenopteryx sorbifolia, Psychotria leiocarpa, Cordia americana, Sapium glandulosum, Banara tomentosa, Chrysophyllum marginatum, Nectandra megapotamica and Pilocarpus pennatifolius. These species showed to be more strongly related to the fertility gradient (soils with $\mathrm{Ca}, \mathrm{Mg}, \mathrm{K}$ ). The preference of these species for more fertile soils was registered in previous studies (CARVALHO, 2003; CARVALHO, 2006).

For the water spring 2 (WS2), the following were indicator species: Cupania vernalis, Celtis iguanaea, Casearia sylvestris, Myrocarpus frondosus and Ocotea indecora. Except for this last one, the other species were located to the right of the ordenation plot (Figure 2B), with a preference for fertile soils, as indicated by CARVALHO (2003, 2006). In the negative side of the figure there is Ocotea indecora, indicating that it does not depend on the concentration of $\mathrm{K}$ in the soil.

For the water spring 3 (N3), the following were indicator species: Cryptocarya moschata, Ilex paraguariensis, Myrceugenia miersiana and Dicksonia sellowiana, which are species more related to more acid and more aluminous soils (REITZ et al., 1983; CARVALHO, 2003, 2006).

Most of occurring species are generalist. In this group, there is a predominance of species without environmental preferences or that tolerate more the edaphic variations, there are the species that are never in the edges of the CCA diagram, always tending towards its center: Ateleia glazioveana, Alsophila setosa, Allophylus guaraniticus, Annona rugulosa, Campomanesia xanthocarpa, Myrsine umbellata, Luehea divaricata, Allophylus edulis, Araucaria angustifolia, Nectandralanceolata, Caseariadecandra, Coussarea contracta, Dalbergia frutescens, Matayba elaeagnoides and Styrax leprosus. The plasticity of these where also established by CARVALHO (2003, 2006, 2008). The higher environmental uniformity showed by the low eigenvalues in both axis of CCA (Figure 2) indicates the occurrence of a higher number of generalist species.

For the water spring 1 (WS1), with soils with a better fertility, the analysis of indicator species presented a higher number of species. Normally, places where the species Nectandra megapotamica can be found have elevated $\mathrm{pH}$ values, smaller amount of aluminum and; consequently, higher natural fertility. Conversely, in places where Ilex paraguariensis is present (water spring 3), the soils are more acid and with a higher aluminium saturation. The preference for acid soils by Ilex paraguariensis was already verified by other authors, such as BENEDETTI (2012) and CARVALHO (2003).

Cryptocarpa moschata and Myrceugenia miersiana are species that only occurs in the water spring 3 (WS3). At this spring there is a predominance of soils with a higher aluminium saturation. In water spring 1 (WS1), the species located more in the edge of the ordering diagram (Figure 2), which is strongly related to more fertile and less acid soils, was Pilocarpus pennatifolius.

Coussarea contracta is a sub-forest species which shows a high density in all the water springs (Table 3 ) and with most of its individuals having less than $10 \mathrm{~m}$. It also shows a low environmental preference, as shadow species, even if there is a higher concentration in springs with soils with a higher aluminium saturation. BLUM \& RODERJAN (2007), when studying a gradient of the Dense Ombrophylous Forest in Serra da Prata, $\mathrm{PR}$, also observed that this species did not have an environmental preference. 


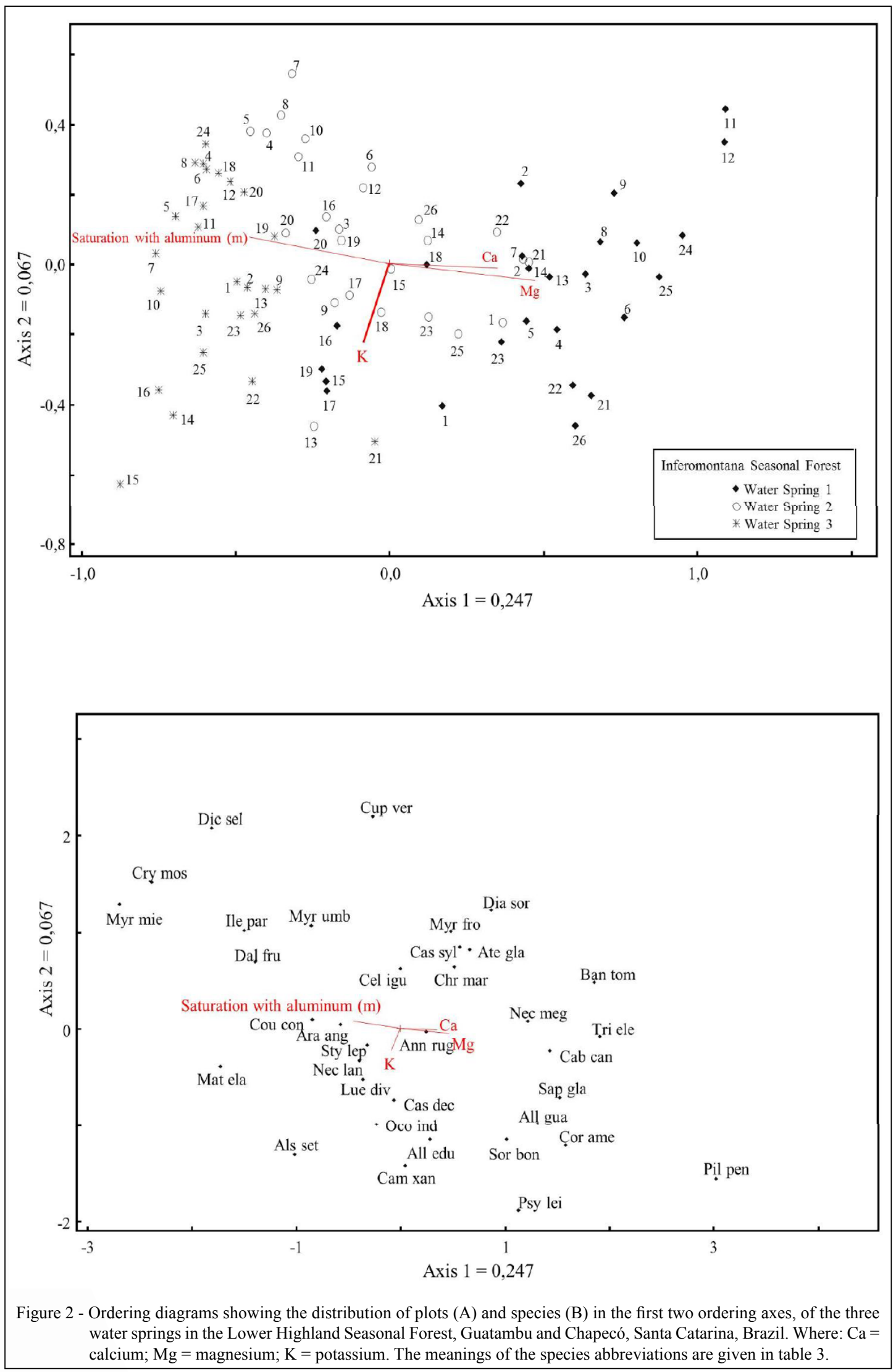

Ciência Rural, v.48, n.11, 2018. 
Table 3 - Indicator Species Analysis (ISA) and generalist, held on three water springs in Lower Highland Seasonal Forest, Guatambu and Chapecó, Santa Catarina, Brazil.

\begin{tabular}{|c|c|c|c|c|c|c|c|c|}
\hline \multirow[t]{2}{*}{ Species indicator by water spring } & \multirow[t]{2}{*}{ LSN } & \multirow[t]{2}{*}{ OIV } & \multicolumn{3}{|c|}{ EIV } & \multirow[t]{2}{*}{ WS1 } & \multirow[t]{2}{*}{ WS2 } & \multirow[t]{2}{*}{ WS3 } \\
\hline & & & Average & $s$ & $p$ & & & \\
\hline \multicolumn{9}{|l|}{ Water Spring 1} \\
\hline Sorocea bonplandii & Sor bon & 44.4 & 12.1 & 3.85 & $* * *$ & 16 & 1 & 1 \\
\hline Trichilia elegans & Tri ele & 64.1 & 18.8 & 4.46 & ${ }^{* * *}$ & 60 & 9 & 3 \\
\hline Cabralea canjerana & Cab can & 28.8 & 11.5 & 3.77 & ** & 12 & 2 & 2 \\
\hline Diatenopteryx sorbifolia & Dia sor & 45.0 & 27.2 & 4.40 & ** & 89 & 99 & 2 \\
\hline Psychotria leiocarpa & Psy lei & 24.5 & 8.3 & 3.42 & $* *$ & 10 & 1 & 0 \\
\hline Cordia americana & Cor ame & 34.1 & 17.6 & 4.44 & ** & 39 & 27 & 0 \\
\hline Sapium glandulosum & Sap gla & 25.0 & 12.2 & 3.89 & $* *$ & 13 & 6 & 1 \\
\hline Banara tomentosa & Ban tom & 21.5 & 8.8 & 3.36 & * & 8 & 1 & 1 \\
\hline Chrysophyllum marginatum & Chr mar & 25.6 & 14.6 & 3.93 & $*$ & 15 & 6 & 6 \\
\hline Nectandra megapotamica & Nec meg & 34.0 & 23.1 & 4.31 & $*$ & 41 & 43 & 4 \\
\hline Pilocarpus pennatifolius & Pil pen & 17.6 & 7.5 & 3.44 & * & 11 & 1 & 0 \\
\hline \multicolumn{9}{|l|}{ Water Spring 2} \\
\hline Cupania vernalis & Cup ver & 67.0 & 20.1 & 4.45 & ${ }^{* * *}$ & 11 & 68 & 3 \\
\hline Celtis iguanaea & Cel igu & 32.3 & 9.5 & 3.58 & $* * *$ & 1 & 14 & 0 \\
\hline Casearia sylvestris & Cas syl & 38.7 & 21.8 & 4.33 & $* *$ & 31 & 48 & 2 \\
\hline Myrocarpus frondosus & Myr fro & 32.3 & 16.0 & 4.41 & $* *$ & 12 & 28 & 0 \\
\hline Ocotea indecora & Oco ind & 39.7 & 29.0 & 3.80 & ${ }^{* *}$ & 34 & 60 & 28 \\
\hline \multicolumn{9}{|l|}{ Water Spring 3} \\
\hline Cryptocarpa moschata & Cry mos & 38.5 & 9.3 & 3.49 & $* * *$ & 0 & 0 & 12 \\
\hline Ilex paraguariensis & Ile par & 41.0 & 17.1 & 4.13 & $* * *$ & 1 & 10 & 22 \\
\hline Myrceugenia miersiana & Myr mie & 23.1 & 7.0 & 3.25 & $* *$ & 0 & 0 & 11 \\
\hline Dicksonia sellowiana & Dic sel & 17.9 & 9.5 & 3.54 & * & 0 & 4 & 14 \\
\hline \multicolumn{9}{|l|}{ Generalists } \\
\hline Ateleia glazioviana & Ate gla & 23.9 & 19.3 & 4.12 & ns & 21 & 16 & 7 \\
\hline Alsophila setosa & Als set & 20.0 & 18.1 & 4.92 & ns & 98 & 15 & 75 \\
\hline Allophylus guaraniticus & All gua & 11.5 & 10.4 & 3.61 & ns & 7 & 6 & 1 \\
\hline Annona rugulosa & Ann rug & 15.9 & 16.0 & 3.97 & ns & 12 & 6 & 11 \\
\hline Campomanesia xanthocarpa & Cam xan & 18.5 & 19.2 & 4.28 & ns & 24 & 21 & 10 \\
\hline Myrsine umbellata & Myr umb & 17.1 & 12.5 & 3.89 & ns & 3 & 10 & 5 \\
\hline Luehea divaricata & Lue div & 26.7 & 23.1 & 4.29 & ns & 15 & 26 & 19 \\
\hline Allophylus edulis & All edu & 22.1 & 21.2 & 4.49 & ns & 20 & 23 & 17 \\
\hline Araucaria angustifolia & Ara ang & 12.3 & 14.1 & 3.91 & ns & 6 & 8 & 6 \\
\hline Nectandra lanceolata & Nec lan & 11.4 & 14.3 & 4.09 & ns & 9 & 11 & 6 \\
\hline Casearia decandra & Cas dec & 10.4 & 15.5 & 3.97 & ns & 8 & 10 & 8 \\
\hline Coussarea contracta & Cou con & 40.0 & 35.4 & 2.91 & ns & 72 & 150 & 158 \\
\hline Dalbergia frutescens & Dal fru & 12.6 & 10.5 & 3.70 & ns & 3 & 5 & 7 \\
\hline Matayba elaeagnoides & Mat ela & 11.5 & 9.8 & 3.48 & ns & 0 & 6 & 6 \\
\hline Styrax leprosus & Sty lep & 7.0 & 8.7 & 3.40 & ns & 4 & 2 & 5 \\
\hline
\end{tabular}

Where: LSN = Latin Scientific Name abbreviation; OIV = Observed Indicator Value; EIV = Expected Indicator Value; $s=$ standard deviation; $P=$ significance; WS1, WS2 and WS3 = density of individuals per species per water spring. Where: ns (not significative) $\mathrm{P}>0.05$; $\left(^{*}\right) \mathrm{P}<0.05 ;\left(^{* *}\right) \mathrm{P}<0.01 ;\left(^{* * *}\right) \mathrm{P}<0.001$.

\section{CONCLUSION}

From the results it was concluded that: 1) The three water springs are well conserved, with a floristic composition and structure that are expected from the typology of the Lower Highland Seasonal Forest; 2) There was the occurrence of specific groups of indicator species for each springs, which may be indicated for springs recovery with similar soil chemical characteristics; 3) Most species are 
classified as generalists, because they are more plastic and do not depend on chemical conditions of the soil. So, they are the most indicated species for initial recovery of springs and/or ciliate forests of the Lower Highland Seasonal Forest. With highlight to Ateleia glazioveana, Campomanesia xanthocarpa, Luehea divaricata and Allophylus edulis some pioneer and other early species, adaptable to degraded areas; 4) Cryptocarpa moschata and Myrceugenia miersiana were predominant in soils with higher saturation by aluminum, being indicated for the recovery of environments with these characteristics; 5) In less degraded areas, with fertile and less acidic soils, it is recommended to plant Pilocarpus pennatifolius and Nectandra megapotamica, because they occur in greater abundance in these places; 6) The species with lower density (rare ones) must be used after the initial overlay of the area in restoration process, having the maintenance of the local floristic diversity as main function; 7) The edaphic variables that most influenced the distribution of the species were: calcium, magnesium, potassium and aluminum saturation.

\section{DECLARATION OF CONFLICTING INTERESTS}

The authors declare no conflict of interest with respect to the research, authorship, and/or publication of this article.

\section{ACKNOWLEDGEMENTS}

To the directors and staff of the Chapecó National Forest for allowing the data collection in its areas, to the board and field staff of the Centro de Pesquisa para Agricultura Familiar (CEPAF)/Empresa de Pesquisa Agropecuária e Extensão Rural de Santa Catarina (EPAGRI) for the support during the data collection, to the Empresa Brasileira de Pesquisa Agropecuária (EMBRAPA) for the scholarship and to Professor Dr. Marcos Sobral for the identification of the species not identified in the HDCF of Universidade Federal de Santa Maria (UFSM).

\section{AUTHORS' CONTRIBUTIONS}

PAF, SJL and ECSF conceived, designed and collected the experiments, MPC, PAF, SJL and ECSF carried out the data analysis and interpretation. PAF, MPC and SJL performed statistical analyses of experimental data. PAF, SJL, ECSF and MPC prepared the draft of the manuscript. PAF coordinated the research and writing of the manuscript. All authors critically revised the manuscript and approved of the final version.

\section{REFERENCES}

APG IV. The Angiosperm Phylogeny Group: An update of the Angiosperm Phylogeny Group classification for the orders and families of flowering plants: Botanical Journal of the Linnean Society, London, v.181, n.1, p.1-20, 2016. Available from: <https://watermark. silverchair.com/api/watermark?token=AQECAHi208BE49Ooan9kk hW_Ercy7Dm3ZL_9Cf3qfKAc485ysgAAAg8wggILBgkqhkiG9w0B Bwaggg>. Accessed: Sept. 12, 2017. doi: 10.1111/boj.12385.

BENEDETTI, E.L. Tolerância da erva-mate (Ilex paraguariensis St. Hil.) ao alumínio. 2012. 72f. Tese (Doctor Scientiae) Universidade Federal de Viçosa.

BLUM, C.T.; RODERJAN, C.V. Espécies indicadoras em um gradiente da Floresta Ombrófila Densa na Serra da Prata, Paraná, Brasil. Revista Brasileira de Biociências, Porto Alegre, v. 5, supl. 2, p. 873-875, 2007. Available from: $<$ http://www.ufrgs.br/seerbio/ ojs/index.php/rbb/article/view/720/602>. Accessed: Jul. 21, 2017.

CALLEGARO, R.M. et al. Estrutura do componente arbóreo de uma floresta estacional decidual ripária em Jaguari, RS. Ciência Rural, Santa Maria, v.42, n.2, p.305-311, 2012. Available from: $<$ http://www.scielo.br/pdf/cr/v42n2/a5212cr5295.pdf $>$. Accessed: Aug. 19, 2017. doi: 10.1590/S0103-84782012000200019.

CALHEIROS, R. de O. et al. Preservação e Recuperação das Nascentes. Piracicaba: Comitê das Bacias Hidrográficas dos Rios PCJ - CTRN, 2004

CARVALHO, P.E.R. Espécies arbóreas brasileiras. Brasília: EMBRAPA, 2003. 1039p. v.1.

CARVALHO, P.E.R. Espécies arbóreas brasileiras. Brasília: EMBRAPA, 2006. 627p. v.2.

CARVALHO, P.E.R. Espécies arbóreas brasileiras. Brasília: EMBRAPA, 2008. 593p. v.3.

CLAESSEN, M.E.C. (Org.). Manual de métodos de análise de solo. 2. ed. rev. e atual. Rio de Janeiro: EMBRAPA-CNPS, 1997. 212p.

DUFRÊNE, M.; LEGENDRE, P. Species assemblages and indicator species: the need for flexible asymmetrical approach. Ecological Monographs, Washington, v.67, n.3, p.345-366, 1997. Available from: <http://onlinelibrary.wiley.com/doi/10.1890/0012615(1997)067[0345:SAAIST]2.0.CO;2/epdf> . Accessed: May 29, 2017. doi: 10.1890/0012-9615(1997)067[0345:SAAIST]2.0.CO;2.

ESPÍRITO-SANTO, F.D.B. et al. Variáveis ambientais e a distribuição de espécies arbóreas em um remanescente de Floresta Estacional Semidecídua Montana no Campus de Universidade Federal de Lavras, MG. Acta Botânica Brasílica, Belo Horizonte, v.16, n.3, p.331-356, 2002. Available from: $<$ http://www.scielo.br/pdf/abb/v16n3/15396.pdf $>$. Accessed: Mar. 27, 2017. doi: 10.1590/S0102-33062002000300006.

GASPER, A.L. et al. Inventário Florístico Florestal de Santa Catarina: espécies da Floresta Estacional Decidual. Rodriguésia, Rio de Janeiro, v.64, n.3, p.427-443, 2013. Available from: <http:// www.scielo.br/pdf/rod/v64n3/v64n3a01.pdf >. Accessed: Nov. 12, 2016. doi: 10.1590/S2175-78602013000300001.

GAUCH, M.G. Multivariate Analysis in Community ecology. Cambridge: Cambridge University Spress, 1982. 137p.

GOMES, J.F. et al. Classificação e crescimento de unidades de vegetação em floresta Ombófila Mista, São Francisco de Paula, RS. Ciência Florestal, Santa Maria, v.18, n.1, p.93-107, 2008. Available from: <https://periodicos.ufsm.br/cienciaflorestal/issue/view/47/ showToc $>$. Accessed: Oct. 1, 2017. doi: 10.5902/19805098460. 
IBGE. Instituto Brasileiro de Geografia e Estatística. Manual Técnico da Vegetação Brasileira: Sistema fitogeográfico, Inventário das formações florestais e campestres, Técnicas e manejo de coleções botânicas, Procedimentos para mapeamentos. Rio de Janeiro: 2012. 271p.

KANIESKI, M.R. et al. Quantificação da diversidade em Floresta Ombrófila Mista por meio de diferentes Índices Alfa. Scientia Forestalis, Piracicaba, v.38, n.88, p.567-577, 2010. Available from: <http://www.ipef.br/publicacoes/scientia/nr88/cap03.pdf $>$. Accessed: Mar. 08, 2017.

KLAUBERG, C. et al. Florística e estrutura de um fragmento de floresta ombrófila mista no Planalto Catarinense. Biotemas, Florianópolis, v.23, n.1, p.35-47, 2010. Available from: <https:// periodicos.ufsc.br/index.php/biotemas/article/view/21757925.2010v23n1p35/17521>. Accessed: Mar. 14, 2017. doi: $10.5902 / 198050988449$.

LEITE, P.F.; KLEIN, R.M. Vegetação. In: IBGE. Geografia do Brasil: Região Sul. Rio de Janeiro: Instituto Brasileiro de Geografia e Estatística, 1990. p.113-150.

LONGHI, S.J. et al. Aspectos fitossociológicos de fregmento de Floresta Estacional Decidual, Santa Maria, RS. Ciência Florestal, Santa Maria, v. 10, n. 2, p. 59-74, 2000. Available from: <https:// periodicos.ufsm.br/cienciaflorestal/issue/view/26/showToc $>$. Accessed: Nov. 16, 2017.

McCUNE, B.; MEFFORD, M.J. PC-ORD: multivariate analysis of ecological data. Version 5.0. Oregon: PC-ORD, 2006. 40p.

MUELlER-DOMBOIS, D.; ELLENBERG, H. Aims and methods of vegetation ecology. New York: The blackburn Press, 2002. 547p.

NASCIMENTO, A.R.T. et al. Estrutura e classificação de um remanescente de floresta ripária no município de Lages, SC. Ciência Florestal, Santa Maria, v. 21, n. 2, p. 209-218, 2011. Available from: $<$ https://periodicos.ufsm.br/cienciaflorestal/issue/view/113/ showToc>. Accessed: Apr. 22, 2017. doi: 10.5902/198050983224.

OLIVEIRA-FILHO, A.T. Classificação das fitofisionomias da América do Sul cisandina tropical e subtropical: proposta de um novo sistema - prático e flexível - ou uma injeção a mais de caos? Rodriguésia, Rio de Janeiro, v.60, n.2, p.237-258, 2009. Available from: <http://rodriguesia.jbrj.gov.br/FASCICULOS/ rodrig60 2/01-076-08.pdf $>$. Accessed: Jul. 01, 2018. doi: $10.1590 / 2175-7860200960201$

PINTO, L.V.A. et al. Distribuição das espécies arbóreo-arbustivas ao longo do gradiente de umidade do solo de nascentes pontuais da bacia hidrográfica do ribeirão santa cruz, Lavras, MG. Cerne, Lavras, v.11, n.3, p. 294-305, 2005. Available from: <http://www. redalyc.org/pdf/744/74411308.pdf $>$. Accessed: Jul. 01, 2018.

PRADO, H. do. Solos do Brasil-gênese, morfologia, classificação, levantamento, manejo de solos. 4.ed. Piracicaba, 2005. 281p.
REITZ, R. et al. Projeto Madeira do Rio Grande do Sul. Sellowia, Itajaí, n.34-35, p.1-525, 1983.

R DEVELOPMENT CORE TEAM. R: A Language and Environment for Statistical Computing. Viena: R Foundation for Statistical Computing, 2006.

RODRIGUES, R.R. et al. Large-scale ecological restoration of high-diversity tropical forests in SE Brazil. Forest Ecology and Management, v. 261, p. 1605-1613, 2011. Available from: $<$ http://elti.fesprojects.net/2011Corridors1Colombia/rodrigues et_al._2011.pdf $>$. Accessed: Jun. 06, 2018. doi: 10.1016/ foreco.2010.07.005

SCHNEIDER, G.; ROCHA, F.S. Levantamento florístico e fitossociológico do componente arbóreo de um fragmento de Floresta Estacional Decidual em São Miguel do Oeste, Santa Catarina. Biotemas, Florianópolis, v. 27, n. 2, p. 43-55, 2014. Available from: <https://periodicos.ufsc.br/index.php/biotemas/ article/view/2175-7925.2014v27n2p43/26601>. Accessed: Sept. 24, 2016. doi: 10.5007/2175-7925.2014.v27n2p43.

SOIL SURVEY STAFF (SSS). Keys to soil taxonomy, 12th ed. USDANatural Resources Conservation Service, Washington, DC. 2014.

TEDESCO, M.J. et al. Análise de solo, plantas e outros materiais. 2.ed. Porto Alegre: Universidade Federal do Rio Grande do Sul, 1995. 174p.

TER BRAAK, C.J.F. Canonical correspondence analysis: a new eigenvector technique for multivariate direct gradient analysis. Ecology, Ithaca, v.67, n.5, p.1167-1179, 1986. Available from: $<$ http://onlinelibrary.wiley.com/doi/10.2307/1938672/epdf $>$. Accessed: Apr. 30, 2017. doi: 10.2307/1938672.

TER BRAAK, C.J.F. The analysis of vegetation-environment relationships by canonical correspondence anlysis. Plant Ecology, Dordrecht, v. 69, n. 3, p. 69-77, 1987. Available from: <https:// link.springer.com/content/pdf/10.1007\%2FBF00038688.pdf $>$. Accessed: Apr. 30, 2017.

TER BRAAK, C.J.F. CANOCO - A FORTRAN program for canonical community ordination by (Partial) (Detrended) (Canonical) correspondence analysis and redundancy analysis, version 2.1. Wageningen: Technical report LWA-88-2, TNO, Institute of Applied Computer Science. 1988. 389p.

TER BRAAK, C.J.F. Ordination. In: JONGMAN, R.H.G.; TER BRAAK, C.J.F.; VAN TONGEREN, O.F.R. (Orgs.). Data analysis in community and landscape ecology. Wageningen: 1995. p.91-173.

VACCARO, S.; LONGHI, S.J. Análise fitossociológica de algumas áreas remanescentes da floresta do Alto Uruguai, entre os rios Ijuí e Turvo, no Rio Grande do Sul. Ciência Florestal, Santa Maria, v.5, n.1, p.33-53, 1995. Available from: <https://periodicos.ufsm. br/cienciaflorestal/article/view/309/176>. Accessed: Oct. 13, 2017.

VELOSO, H P. et al. Classificação da vegetação brasileira, adaptada a um sistema universal. Rio de Janeiro: IBGE, 1991. 123p. 